\title{
Is Currency Appreciation or Depreciation Expansionary in Kosovo?
}

\author{
Yu Hsing *
}

\begin{abstract}
Applying an extended IS-MP-AS model (Romer, 2000), this paper shows that real depreciation of the euro raises real GDP in Kosovo and that a lower real lending rate in the euro area, a higher real GDP in Germany, a lower real oil price, or a lower expected inflation rate would help increase real GDP. More government deficit spending as a percent of GDP does not affect real GDP.
\end{abstract}

Keywords: Real depreciation or appreciation; Budget deficits; Interest rates; Oil prices

JEL Classification: F41, E62

\section{Introduction}

Kosovo's economy shows strengths as well as weaknesses. According to the International Monetary Fund, the growth rate of real GDP reached 3.5\% in 2017. Even during 2008-2010, the economic growth rate was still more than 3\%. Since 2013, the inflation rate has been lower than $2 \%$. Since 2014, its net borrowing as a percent of GDP has been below 3\%. Its general government gross debt as a percent of GDP rose gradually from $15.628 \%$ in 2010 to $23.477 \%$ in 2017, suggesting that Kosovo has pursued a relatively prudent fiscal policy as its debt-to-GDP ratio was substantially less than the 60\% threshold under the Maastricht Treaty. In 2016, Kosovo exported 1.3463 billion euro of goods and services and imported 3.0721 billion euro of goods and services, resulting in a trade deficit of 1.7258 billion euro. Mainly due to the trade deficit, Kosovo recorded a current account deficit of 9.699\% of GDP in 2016, indicating that there would be room for improvement in international trade. The relatively high unemployment rate of $27.5 \%$ in 2016 suggests that it was much higher than the average unemployment rate in the European Union and that attracting more

\footnotetext{
* Yu Hsing is at Southeastern Louisiana University, Hammond, LA, USA.
} 
foreign direct investment (FDI) or stimulating domestic investment spending in order to create more job opportunities is an important agenda for the government to pursue.

Kosovo's major trading partners include Albania, China, Germany, Italy, Switzerland and Turkey. Kosovo is a member of the Central European Free Trade Agreement (CEFRA), which was signed by Albania, Bosnia and Herzegovina, Kosovo, Macedonia. Moldova, Montenegro and Serbia. During 1980-1990, the Yugoslav dinar was the official currency used by the Kosovan people. During 1991-1999, due to high inflation and loss of financial credibility caused by the wars in former Yugoslavia, the German mark became the de facto currency for daily transactions. In 1999, the German mark was adopted as the official currency. In 2002, in order to stabilize the exchange rate, facilitate international trade, reduce potential high inflation and enhance foreign capital inflows, Kosovo adopted the euro as the de facto currency unilaterally without being a member of the Eurozone. Because of the adoption of the euro, Kosovo cannot manage or control the exchange rate. Although the adoption of the euro provided macroeconomic and financial stability but failed to deliver microeconomic benefits such as stimulation of exports (Bunjaku, 2015).

This study focuses on the impact of real appreciation or depreciation on aggregate output in Kosovo. Other relevant macroeconomic variables will be considered as well. The paper extends the IS-MP-AS model (Romer, 2000). The advantage of this model is that monetary policy responds to the inflation rate, which is consistent with monetary policy of the Central Bank of the Republic of Kosovo to pursue price stability.

\section{Literature survey}

There are several recent articles studying the effect of the exchange rate on aggregate output or the trade balance for the Southern or Eastern European countries.

In studying the $\mathbf{J}$ curve hypothesis in Croatia, Stučka (2003) finds that there is deterioration of the trade balance after depreciation and that it takes two and half years to improve the trade balance. The study for Croatia may be relevant for Kosovo because these two countries had a similar background in the former Socialist Federal Republic of Yugoslavia.

Using a sample of nine East European countries, Bahmani-Oskooee and Kutan (2006) indicate that real depreciation raises real GDP in Poland, Slovakia, Latvia and Belarus in the short run, reduces real GDP in Russia, Hungary, the Czech Republic and Estonia in the short run, and has no impact on real GDP in Lithuania in the short run, and does not have impact on real GDP in the long run.

Based on a sample of eleven Eastern European countries during 1990.M1 - 2005. M6, Bahmani-Oskooee and Kutan (2009) examine the effect of depreciation on the 
trade balance and find that the J-curve effect exists in Russia, Bulgaria and Croatia, suggesting that after currency depreciation, the trade balance would will worse off in the short run and improve in the long run.

Based on an annual sample during 2009-2011, Kurihara (2013) shows that exchange rate volatility is harmful to international trade in developing countries including Kosovo and that financial development helps international trade in developed countries.

Using a sample of seventeen countries in the Eastern and Southern European region during 2000-2015, Begović and Kreso (2017) reveal that real depreciation hurts the balance of trade and suggest that currency depreciation should not be used as a tool to improve the trade balance in transition economies.

\section{The model}

Extending Romer (2000), we can express the IS function, the monetary Policy (MP) function, and the aggregate supply (AS) function as:

$$
\begin{aligned}
& Y=f\left(Y, G, T, L(R), E, Y^{w}\right) \\
& R=g\left(\pi-\pi^{*}, Y-Y^{*}, R^{w}\right) \\
& \pi=h\left(\pi^{e}, Y-Y^{*}, O, E\right)
\end{aligned}
$$

where

$\mathrm{Y}=$ real GDP in Kosovo,

$\mathrm{G}=$ government spending,

$\mathrm{T}=$ government tax revenue,

$\mathrm{L}=$ the lending rate,

$\mathrm{R}=$ the policy rate,

$\mathrm{E}=$ the real effective exchange rate,

$\mathrm{Y}^{\mathrm{w}}=$ world real income,

$\pi=$ the inflation rate,

$\pi^{*}=$ the inflation target,

$\mathrm{Y}^{*}=$ potential real GDP,

$\mathrm{R}^{\mathrm{w}}=$ the world real interest rate,

$\pi^{e}=$ the expected inflation rate, and

$\mathrm{O}=$ real crude oil price per barrel. 
Suppose that the inflation target and potential real GDP are constants in the short run. Solving the three endogenous variables simultaneously, we can find equilibrium real GDP as:

$$
\bar{Y}=x\left(E, G-T, R^{w}, Y^{w}, O, \pi^{e}\right)
$$

Because real GDP shows seasonal patterns in the sample, the estimated equation becomes

$$
\begin{array}{r}
\bar{Y}=x\left(E, G-T, R^{w}, Y^{w}, O, \pi^{e}, S 2, S 3, S 4\right) \\
? \quad ? \quad-+-++++
\end{array}
$$

where S2, S3 and S4 represent the binary variables for the second, third and fourth quarters.

Real depreciation of the euro tends to stimulate exports, reduce imports, raise import prices and domestic inflation, and reduce capital inflows. Conversely, real appreciation tends to reduce exports, increase imports, reduce import prices and domestic inflation, and increase capital inflows. Hence, the net impact is unclear.

More government deficit spending shifts aggregate demand to the right, but it may raise the interest rate, reduce private spending, and shift aggregate demand to the left. Barro $(1974,1989)$ maintains that deficit- or debt-financed spending has a neutral effect on aggregate output in the long run. Cebula (1997, 2014a, 2014b), Cebula and Cuellar (2010) and Cebula, Angjellari-Dajci and Foley (2014) find that more government deficit spending raises the real interest rate and tends to crowd out private spending.

The Central Bank of the Republic of Kosovo is expected to determine its policy interest rate in response to the world interest rate. A higher real crude oil price or expected inflation rate is likely to shift short-run aggregate supply to the left, raise the inflation rate, and reduce real GDP.

\section{Empirical results}

The data were collected from the International Financial Statistics published by the International Monetary Fund. Real GDP is measured in million euros. An increase in the real effective exchange rate means real appreciation, and vice versa. Government deficit is measured as a percent of GDP. The lending rate in the euro area minus the inflation rate in the euro area is selected to represent the world real interest rate. Real world income is represented by Germany's real GDP. The real crude oil price per barrel is measured in the euro. The expected inflation rate is estimated as the average 
inflation rate of the past six quarters. The sample ranges from 2011.Q1 to 2017.Q2 and has a total of 26 observations. The data for real GDP are unavailable before 2011.Q1.

Figure 1 presents the scatter diagram between real GDP and the real effective exchange rate. They seemed to have a negative relationship during the sample period. It suggests that real appreciation would reduce real GDP whereas real depreciation would raise real GDP.

To test whether these time series variables have a stable long-term relationship, the augmented Dickey-Fuller test on regression residuals is employed. The value of the test statistic is estimated to be -4.8515 , and the critical value at the $1 \%$ is -4.3743 . Hence, these variables are cointegrated.

Figure 1. Scatter Diagram between Real GDP (RGDP) and the Real Effective Exchange Rate (REER)

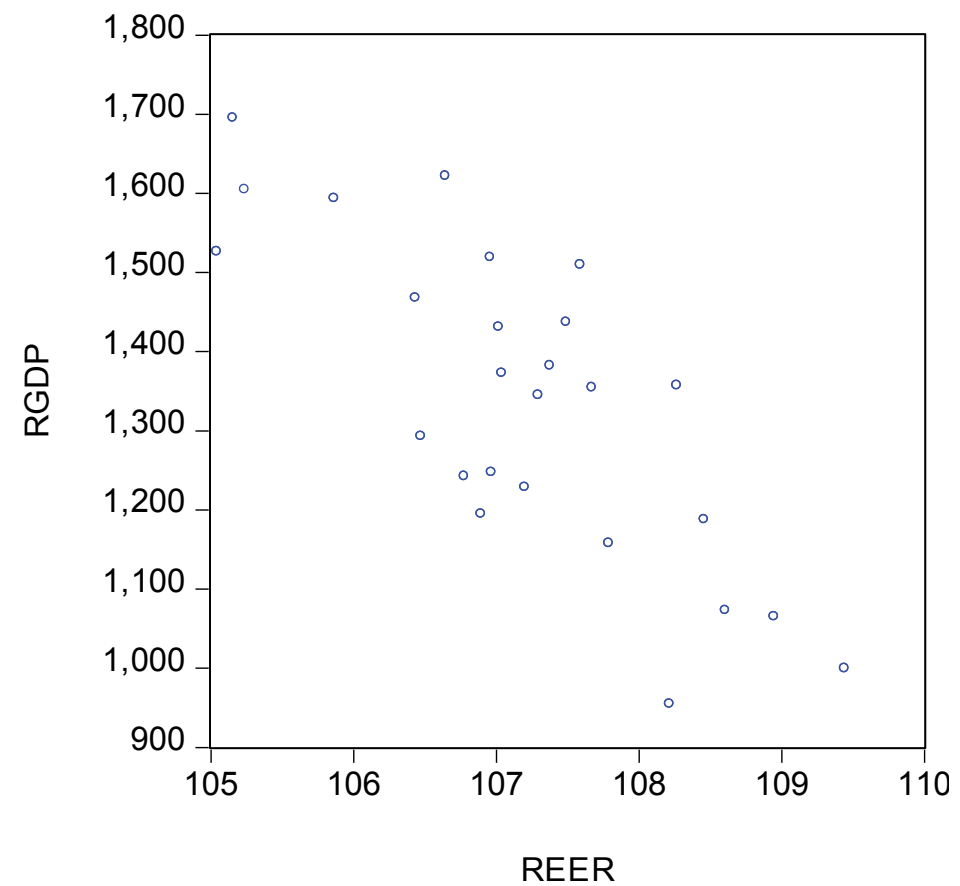

Table 1 presents the estimated regression and related statistics. Approximately 97.94\% of the change in real GDP can be explained by the right-hand side variables with significant coefficients. Real GDP has a positive relationship with Germany's real GDP and three seasonal binary variables, a negative relationship with the real effective exchange rate, the real lending rate in the euro area, the real oil price and the expected inflation rate, and an insignificant relationship with the government deficit 
spending as a percent of GDP. The mean absolute percent error (MAPE) of $1.7863 \%$ suggests that the forecast error is relatively small.

Table 1. Estimated Regression of $\log ($ Real GDP) in Kosovo

\begin{tabular}{|l|c|c|c|}
\hline & Coefficient & z-Statistic & Probability \\
\hline Constant & 5.213801 & 419.1379 & 0.0000 \\
\hline Log(real effective exchange rate) & -2.139133 & -235.3486 & 0.0000 \\
\hline Government deficit/GDP ratio & -0.003111 & -1.166390 & 0.2435 \\
\hline Real lending rate in the euro area & -0.009151 & -2.155358 & 0.0311 \\
\hline Log(real GDP in Germany) & 0.886895 & 365.2028 & 0.0000 \\
\hline Log(real oil price) & -0.007950 & -5.952194 & 0.0000 \\
\hline Expected inflation rate & -0.025364 & -955.0177 & 0.0000 \\
\hline Second quarter & 0.194198 & 18.25464 & 0.0000 \\
\hline Third quarter & 0.257650 & 30.70110 & 0.0000 \\
\hline Fourth quarter & 0.210847 & 31.30506 & 0.0000 \\
\hline R-squared & 0.979375 & & \\
\hline Akaike information criterion & -4.307721 & & \\
\hline Schwarz criterion & -3.727061 & & \\
\hline Sample period & $2011 . \mathrm{Q} 1-2017 . \mathrm{Q} 2$ & & \\
\hline Methodology & GARCH & & \\
\hline MAPE & $1.7863 \%$ & & \\
\hline
\end{tabular}

Notes:

GARCH stands for the generalized autoregressive conditional heteroscedasticity.

MAPE is the mean absolute percent error.

Specifically, a $1 \%$ increase in the real effective exchange rate would lead to a decrease in real GDP by $2.1391 \%$, suggesting that a $1 \%$ real appreciation (depreciation) would result in a $2.1391 \%$ decline (increase) in real GDP. This finding suggests that the positive effect of real depreciation of the euro such as more exports dominates the negative effect of real depreciation such as higher import costs and domestic inflation. The insignificant coefficient of the government deficit-to-GDP ratio indicates that deficit-financed government spending tends to be ineffective in raising real GDP due to the crowding-out effect reducing private spending. The negative significant coefficient of the real lending rate in the euro area implies that the real lending rate in Kosovo responds to a change in the real lending rate in the euro area positively. When real GDP in Germany rises $1 \%$, Kosovo's real GDP would increase by $0.8869 \%$. Although the coefficient of the real oil price is negative and significant, the impact measured in percent change is relatively small. The negative and significant coefficient of the expected inflation rate implies that a higher expected inflation tends to shift short-run aggregate supply to the left, raise the inflation rate and reduce real GDP. 


\section{Summary and conclusions}

This paper has examined the impacts of real appreciation or depreciation and other related macroeconomic variables on aggregate output in Kosovo. An extended ISMP-AS model (Romer, 2000) is applied. Real depreciation of the euro, a lower real lending rate in the euro area, a higher real GDP in Germany, a lower real oil price and a lower expected inflation rate would raise real GDP in Kosovo. More government deficit spending as a percent of GDP does not affect real GDP mainly due to the crowding-out effect.

There are several policy implications. Real depreciation instead of real appreciation raises real GDP. Hence, the positive effects of real depreciation such as improvement in the trade balance dominate the negative effects. The authorities may need to exercise caution in pursuing expansionary fiscal policy as more deficit spending as a percent of GDP does not affect real GDP. Because the euro is the national currency, its monetary policy is constrained by the decision made by the European Central Bank.

\section{REFERENCES}

Bahmani-Oskooee, M. and Kutan, A. M., 2006. Are devaluations contractionary in emerging economies of Eastern Europe? working paper, pp. 1-17.

Bahmani-Oskooee, M. and Kutan, A. M., 2009. The J-curve in the emerging economies of Eastern Europe. Applied Economics, 41, 2523-2532.

Barro, R. J., 1974. Are government bonds net wealth? Journal of Political Economy, 82, 10951117.

Barro, R. J., 1989. The Ricardian approach to budget deficits. Journal of Economic Perspectives, 3, 37-54.

Begović, S. and Kreso, S., 2017. The adverse effect of real effective exchange rate change on trade balance in European transition countries. Zbornik radova Ekonomskog fakulteta u Rijeci: časopis za ekonomsku teoriju i praksu, 35(2), 277-299.

Berisha, A., 2012. Foreign trade of Kosovo and impact of fiscal policy. European Scientific Journal, ESJ, 8(9).

Bunjaku, M. F., 2015. Exchange rate regimes-A periodical overview and a critical analysis of exchange rate regimes in Kosovo. Academic Journal of Business, Administration, Law and Social Sciences, 1(1), 40-46.

Cebula, R. J., 1997. An empirical note on the impact of the federal budget deficit on ex ante real long term interest rates, 1973-1995. Southern Economic Journal, 63, 1094-1099.

Cebula, R. J., 2014a. Impact of federal government budget deficits on the longer-term real interest rate in the US: evidence using annual and quarterly Data, 1960-2013.

Cebula, R. J., 2014b. an empirical investigation into the impact Of US federal government budget deficits on the real interest rate yield on intermediate-term treasury issues. 1972-2012. Applied Economics, 46, 3483-3493.

Cebula, R. J., and Cuellar, P., 2010. Recent evidence on the impact of government budget deficits on the ex ante real interest rate yield on Moody's baa-rated corporate bonds. Journal of Economics and Finance, 34, 301-307. 
Cebula, R. J., Angjellari-Dajci, F., and Foley, M., 2014. An exploratory empirical inquiry into the impact of federal budget deficits on the ex post real interest rate yield on ten year treasury notes over the last half century. Journal of Economics and Finance, 38, 712-720.

Dushi, A. K. and Merovci, S., 2014. The effects of exchange rate market in the economy of Kosova. Acta Universitatis Danubius: Oeconomica, 10(4).

Kelmendi, V. and Sylqa, D., 2013. Reflections of the global financial crisis and the performance of macro-economic development in Kosovo. Academic Journal of Interdisciplinary Studies, 2(9), 310 .

Kukaj, H., 2017. Global financial crisis and its impact in the countries in transition-with special emphasis in Kosovo.

Kurihara, Y., 2013. Effects of exchange rate fluctuations and financial development on international trade: Recent experience. International Journal of Business, Management and Economics Research, 4(5), 793-801.

Romer, D. (2000) Keynesian macroeconomics without the LM curve, Journal of Economic Perspectives, 14, 149-169.

Stučka, Tihomir., 2003. The impact of exchange rate changes on the trade balance in Croatia." Croatian National Bank Working Paper Series. No. W - 11, October 2003.

Uvalic, M., 2012. Transition in Southeast Europe: Understanding economic development and institutional change. In Economies in Transition (pp. 364-399). Palgrave Macmillan, London. 